\title{
İş Yaşamında Yalnızlık, Çalışmaya Tutkunluk, Yaşam Tatmini ve İş Tatmini Arasındaki İlişkilerin İncelenmesi: Turizm Sektörü İncelemesi \\ Hüseyin BOZ ${ }^{a}$, Hale ALAN ${ }^{\mathrm{b}}$
}

Özet

İş yaşamında sağlıklı iletişim kuramayan ve yeteri kadar destek göremediğini düşündüğü için yalnızlık hissine kapılan bir çalışan, iş tatminsizliği ve yaşam tatminsizliği yaşamakta ve çalışmaya tutkunluğunun azalması gibi olumsuz durumlarla birlikte çalıştığı işletmeye zarar verebilmektedir. Bu çalışmanın amacı iş yaşamında yalnızlık ile yaşam tatmini, iş tatmini ve çalışmaya tutkunluk kavramları arasındaki ilişkileri kapsamlı ve detaylı olarak turizm sektörü çalışanları örneklemi üzerinde incelemektir. Araştırma verileri Antalya'da turizm sektöründe çoğunluğunun yönetici olarak görev yaptığ1 338 çalışandan basit rastgele örnekleme yöntemi kullanılarak toplanmıştır. Yapısal eşitlik modellemesi yardımıyla gerçekleştirilen yol analizleri ile bu çalışma iki aşamalı ve 6 hipoteze dayanmaktadır. Araştırmada iş yaşamı yalnızlığı ile iş ve yaşam tatmini, çalışmaya tutkunluk ilişkileri ilk bölümde araştırılmıştır. Araştırmanın sonucunda iş tatmininin iş yaşamında yalnızlık ile yaşam tatmini arasında; çalışmaya tutkunluğun iş yaşamında yalnızlık ile yaşam tatmini arasında ve çalışmaya tutkunluğun iş yaşamında yalnızlık ile iş tatmini ilişkisinde aracılık rolü üstlendiği teyit edilmiştir.
Anahtar Kelimeler

İş Yaşamı Yalnızlığı

İş Tatmini

Yaşam Tatmini

Çalışmaya Tutkunluk

Makale Hakkında

Geliş Tarihi: 05.02.2021

Kabul Tarihi: 21.06.2021

Doi: $10.18026 /$ cbayarsos. 875242

\section{Investigation of Relationships between Worklife Loneliness, Work Engagement, Life Satisfaction and Job Satisfaction: Tourism Sector Analysis}

\begin{abstract}
An employee who has a feeling of loneliness due to the fact that he cannot communicate properly in his work life and thinks that he cannot get enough support, experiences job dissatisfaction and life dissatisfaction, and may harm the business he works within negative situations such as a decrease in his work engagement. The aim of this study is to examine the relationships between work-life loneliness and life satisfaction, job satisfaction and work engagement in a comprehensive and detailed way on the sample of tourism sector employees. Research data were collected using a simple random sampling method from 338 employees, most of whom worked as managers in the tourism sector in Antalya. This study is based on two stages and 6 hypotheses with the path analysis performed with the help of structural equation modelling. In the research, the relationships of work-life loneliness, job and life satisfaction, and work engagement were investigated. As a result of the research, job satisfaction is between work-life loneliness and life satisfaction in business life; it has been confirmed that work engagement plays a mediating role between work-life loneliness and life satisfaction, and work engagement plays a mediating role in the relationship between work-life loneliness and job satisfaction in business life.
\end{abstract}

Keywords

\section{Worklife Loneliness \\ Job Satisfaction \\ Life Satisfaction \\ Work Engagement}

\begin{aligned} About Article \\ \hline Received: 05.02 .2021 \\ Accepted: 21.06 .2021\end{aligned}

Doi: $10.18026 /$ cbayarsos. 875242

\footnotetext{
a Dr. Öğr. Üyesi, Akdeniz Üniversitesi, Manavgat Meslek Yüksekokulu, Manavgat, Antalya, E-posta: hboz@akdeniz.edu.tr http://orcid.org/0000-0003-1191-4097

b Dr. Öğr. Üyesi, Akdeniz Üniversitesi, Manavgat Sosyal ve Beşeri Bilimler Fakültesi, Manavgat, Antalya. E-posta: halealan@akdeniz.edu.tr http://orcid.org/0000-0002-2444-1551
} 


\section{Giriş}

Yalnızlık, kişisel sosyal izolasyon yaşanmasına neden olan genellikle başkalarıyla uyum içinde olmama veya çevredeki insanlar tarafından yanlış anlaşılma hissi olarak tanımlanabilir. Yalnızlık hayatın her döneminde yaşanabilen önemli bir psikolojik sorun olmakla beraber sadece özel yaşamda değil, iş yaşamında da yaşanabilir. Çalışma ilişkilerinde yaşanan devrim niteliğindeki dönüşümlerin, uzaktan çalışma uygulamalarının hızlanmasına, iş yeri kavramının değişmesine, iş ilişkileri kurma ve sürdürme konusunda engeller ortaya çıkmasına neden olduğu söylenebilir. Bu ekonomik durgunluğun stresiyle birleşen işyerlerinde günümüzde yaşanılan ilişkilerin nasıl sonuçlar doğuracağı ve hangi davranışları tetikleyeceği merak konusudur.

İş yaşamında yalnızlık, farklı demografi, kıdem ve sektördeki tüm çalışanları etkiler. Teknoloji ve sosyal medya kullanımının artması başta olmak üzere birçok faktörün etkisi ile iş yaşamında yaygınlaşan yalnızlık sorunu insanların psikolojik durumlarını bozmaktadır. Bu zararların başında insan ilişkilerinde güvensizlik ve hayal kırıklığı yaşama korkusu, yabancilaşma, zamanla insan ilişkilerinde çatışmalar yaşanması gelmekte ve depresyona girmeye kadar daha ciddi sağlık sorunlarına da neden olmaktadır. Yalnızlık zamanla gelişim göstererek bireylerin ilişkilerini kontrol altına almakta, diğer insanlarla iletişim kurmaya ayrılan zaman azalmakta ve başkalarıyla zaman geçirmek yerine, yalnız başına kalmanın daha iyi olduğu düşünülmektedir (Mercan vd., 2012). Fakat yalnızlık ilk aşamalarda mutluluk hissi verse de zaman geçtikçe acı veren ve mutsuz hissettiren bir hal alabilmektedir.

$\mathrm{Bu}$ araştırmada çok değişkenli bir araştırma tasarımı kurgulanmış olup bağımsız değişken günümüzde çalışanların çok fazla maruz kaldığı iş yeri yalnızlığıdır. Diğer değişkenler ise iş tatmini, yaşam tatmini ve çalışmaya tutkunluktur. Öncelikle iş tatmini, kişinin işle bağlantılı kendi duyguları ve değerleri, ilerleme fırsatları ve işin özellikleriyle doğrudan ilişkili ve işe yönelik olumlu etki olarak tanımlanabilir. Yaşam tatmini bir kişinin yaşam kalitesinin seçtiği kriterlere göre genel bir değerlendirmesi olarak tanımlanmaktadır (Shin ve Johnson, 1978, s. 478). Çalışmaya tutkunluk ise kendini işe adama, işe anlam yükleme, işi özümseme, yüksek konsantrasyon ve işe dahil olmaya yönelik yüksek enerjiyi temsil etmektedir (Schaufeli vd., 2002, s. 73).

Murthy (2017) Harvard Business Review'daki makalesinde, işyerinde yalnızlığını, günde on beş sigara içmeye, ömür kısaltan faktörlere eşdeğer olduğu ya da giderek artan bir salgın olarak nitelendirmektedir. Yalnız bireyler üzüntü, kaygı, can sıkıntısı, karamsarlık, depresyon, düşük benlik saygısı ve düşük yaşam doyumu duyguları yaşarlar. İş yeri yalnızlığı duygusunun örgütlerde çalışanların iş ve yaşam tatmini kalitesini olumsuz yönde etkilediği belirtilmiştir (Cindiloğlu vd., 2017).

İş yaşamında yalnızlığın en belirgin sonuçları çalışanın iş verimliliğinin, iş ve yaşam tatmininin ve çalışmaya tutkunluğunun azalması olduğu söylenebilir. İş ve yaşam tatmini işyerinde yalnızlık hissi yaşanmasını etkilemektedir. İş yaşamında sağlıklı iletişim kuramayan ve yeteri kadar destek göremediğini düşündüğü için yalnızlık hissine kapılan bir çalışan, iş tatminsizliği ve yaşam tatminsizliği yaşamakta ve çalışmaya tutkunluğunun azalması gibi olumsuz durumlarla birlikte çalıştığ 1 işletmeye zarar verebilir. 
İş tatmini ve çalışmaya tutkunluk ilişkisinde iş tatmini, işin duygusal yönlerine, iş koşullarının veya özelliklerinin değerlendirilmesine odaklanırken, çalışmaya tutkunluk, bir bireyin işten kaynaklanan deneyimlerinin bir açıklaması olarak katılımın fiziksel, duygusal ve bilişsel yönlerine odaklanır. Çalışmaya tutkun birey çalışırken enerjik ve istekli hissederek tüm zorluklarla baş edebilir.

$\mathrm{Bu}$ çalışma iki nedenden dolayı işyeri yalnızlığına odaklanmaktadır. Birincisi, yalnızlık işyerinde yaygın bir sorundur (Özçelik ve Barsade, 2018, s. 11). Bireysel düzeyde yalnızlık, strese, kötü sağlığa, depresif belirtilere (Hawkley ve Cacioppo, 2010), düşük yaşam kalitesine (Theeke vd., 2012), iş tatminin azalmasına (Chan ve Qiu, 2011) ve çalışmaya tutkunluk düzeyinde düşüşe yol açmaktadır. Becerilerini, enerjilerini ve ruh hallerini geliştiren çalışmaya tutkun çalışanlar, bu kaynakları kullanarak işyerinde daha iyi ilişkiler kurmakla birlikte, tutkunluk düzeylerini yükseltebilir ve bunu yaparken iş yerinde yalnızlı̆̆ (Öge vd., 2018). Diğer neden ise işyerinde yalnızlık iş tatmini ve çalışmaya tutkunluğun aracılığıla bireylerin hem yaşam tatminini hem de iş tatminini olumlu yönde etkileyeceği değerlendirilmektedir. Bu nedenlerden dolayı bu çalışmanın amacı iş yeri yalnızlığı ile iş tatmini, yaşam tatmini ve çalışmaya tutkunluk kavramlarının alt boyutlarıyla birlikte aralarındaki ilişkileri kapsamlı ve detaylı olarak ortaya çıkarmak ve yazına katkı sağlamaktır. $\mathrm{Bu}$ amaçla bu çalışmada öncelikle kavramsal açıklamalar ve kapsamlı bir literatür özeti yapılmıştır. Daha sonra kuramsal tartışmalar neticesinde araştırmanın hipotezleri geliştirilmiş olup, araştırmanın yöntemi, bulguları ve sonuçları açıklanmıştır.

\section{Kuramsal Çerçeve ve Hipotezlerin Gelişimi}

\section{İş Yaşamında Yalnızlık}

Yalnızlık alanı, sosyal ihtiyaçlar yaklaşımı, kişilik yaklaşımı ve bilişsel tutarsızlık yaklaşımı olmak üzere genel olarak teorik perspektiflerin üç ana akışı tarafından yönlendirilmiştir. Sosyal ihtiyaçlar yaklaşımı (Weiss, 1973) yalnızlığı sosyal bir eksiklik olarak görür ve hiçbir ilişkinin sosyal ilişkilerin tüm temel hükümlerini karşılayamayacağını savunur. Kişilik yaklaşımı, yalnızlığın utangaçlık, nevrotiklik ve düşük benlik saygısı gibi bozulmuş kişilik özelliklerinden kaynaklandığını savunur. Bilişsel tutarsızlık yaklaşımı, yalnızlığı, değişmiş sosyal algılar ve atıfların bir sonucu olarak görür (Marangoni ve Ickes, 1989, s. 100). Yalnızlı̆̆ı, algılanan ve istenen sosyal ilişkiler arasındaki çelişki olarak tanımlar (Perlman ve Peplau, 1982, s. 2).

İş yaşamı yalnızlığı bireyin sosyal çevreden kaynaklanan tek başına kalma halini ifade etmektedir (Yurcu ve Kocakula, 2015, s. 32). İş yaşamında algılanan yalnızlık iş yerindeki mevcut ilişkiler ile arzu edilen ilişkiler arasındaki olumsuz farklılıkların olması ve bu farklılıkların giderilememesi sonucu ortaya çıkan durum olarak da tanımlanmaktadır (Wright vd., 2006, s. 60). İş yaşamında yalnızlık, bir çalışanın işyerindeki tatminsiz sosyal ilişkiler nedeniyle yaşadığı hoş olmayan bir duygudur (Lam ve Lau, 2012; Wright vd., 2006). Bir başka tanımda ise çalışanların bağlılık ihtiyaçlarının birlikte çalıştıkları kişiler ve çalıştıkları kuruluşlar tarafından karşılanıp karşılanmadığına ilişkin öznel duygusal değerlendirmeleri ve duygularını tanımlamaktadır (Özçelik ve Barsade, 2018, s. 7). Bireyler tüm hayatları boyunca yaşamlarını sağlıklı ve dengeli sürdürmek için diğer bireylerle ilişkiler kurmak zorundadır (Doğan vd., 2009, s. 272). Fakat bireysel toplumlarda örgütler çalışanlarını çeşitli nedenlere bağlı olarak yalnızlığa yöneltebilir. İş yaşamında yalnızlığın ciddi ve çok olumsuz 
sonuçları olabilmekte ve bu durum uzak konumdaki kuruluşlarda çalışanlar için daha da fazla hissedilmektedir (Sekhon ve Srivastava, 2019).

İş yaşamı yalnızlığı duygusal yoksunluk ve sosyal yalnızlık olmak üzere iki boyuttan oluşmaktadır (Wright vd., 2006, s. 66). Duygusal yalnızlık kurulan ilişkilerin özelliğini ifade ederken, ilişki eksikliği dışlanma ve içine kapanma durumlarının yaşanmasına neden olmaktadır. Duygusal yalnızlık hisseden çalışan, iş çevresi tarafından dışlandığına ve umursanmadığını düşünmekte ve bu nedenle duygu ve düşüncelerini gizleyerek içine kapanmaktadır. Kendisini dışlanmış olarak hissettiğinden, bu duygu mutsuz olmasına ve iş arkadaşlarıyla arasına set çekerek giderek daha da içe kapanmaya başlayacak ve onlarla arasına sınır koymaktadır (Çetin ve Alacalar, 2016, s. 196).

Sosyal yalnızlık boyutu ilişkilerin miktarını ifade etmektedir (Wright vd., 2006). Sosyal yalnızlık yaşayan çalışan olumsuz tüm durumları ve hisleri yaşayacaktır. Sosyal yalnızlık, iş ilişkilerinde bireyin iş arkadaşlarıyla sosyalleşememesi, onlarla ilişki, bağ ya da temas kuramaması ya da kendisi ait olduğunu düşündüğü sosyal grup içine girememe halidir. Bu durumlarda kişinin çekingenlik yaşaması, diğerleri tarafından dışlanma ve küçümsenme korkusu yaşaması karşılaşılan durumlardır (Karacaoğlu ve Yumuk, 2014, s. 553).

İş yaşamı yalnızlığının literatürde performans yönetimi, iş tatmini, iş devir oranı, örgütsel bağlılık, örgütsel vatandaşlık, tükenmişlik ve sinizm gibi birçok kavramla ilişkilendirilerek araştırıldığı görülmektedir. Demografik özelliklere göre iş yaşamı yalnızlığının farklılık gösterdiği de birçok çalışmada vurgulanmıştır. Bekarların evlilere göre iş yaşamında daha fazla yalnız kaldıkları belirtilmektedir (Barron vd., 1994; West vd., 1986). İş ve yaşam tatmini bakımından da bekarlar evlilere göre daha yüksek düzeyde tatmine sahiptir (Linn vd., 1985).

\section{İş Yaşamında Yalnızlık ile Yaşam Tatmini İlişkisi}

Yaşam tatmini, bireyin yaşam kalitesini tüm unsurlarıyla değerlendirme ölçüsüdür. İnsanlar hayatlarını kendileri yönlendirmekte ve kendi istek ve beklentileri yaşam kalitesi üzerinde önemli etkiye sahiptir (Kavanagh ve Halpern, 1977, s. 68). Yaşam tatmini insan yaşamının belirli dönemlerine ait olmakla birlikte genel olarak tüm hayat için de geçerli olan bir yaşam tatmini derecesinden söz edilebilir. Yaşam tatmini kişinin mutluluğuyla da yakından ilişkilidir. Genel olarak değerlendirildiğinde yaşam tatmini duygusal mutluluğun öncülü olarak görülmektedir. Yaşam tatmininin kişinin hayatının anlamı, zevk ve deneyimleri arasında bir denge durumuna yol açtığ1 (Schueller ve Seligman, 2010) ve daha mutlu bireylerin hem iş hem de kişisel kapasitede daha fazla meşgul olma ve anlam bulma olasılıklarının daha yüksek olduğu anlayışı (Lyubomirsky vd., 2005) işyeri davranışını incelerken dikkate alınması gereken temel hususlardır.

Yaşam tatminini bir bütün olduğunu ve yaşam kalitesini pozitif gelişimi artırıcı olarak tanımlayanlar da vardır (Veenhoven, 1996). Yaşamdan beklentilerin ne olduğunu kendi kriterlerine göre belirleyenler yaşam tatminini aile, okul, arkadaş ve iş alanlarındaki sahip olunan özellikleri bir bütün olarak değerlendirerek belirlemektedir (Christopher, 1999). Literatüre bakıldığında iş yaşamı yalnızlığının yaşam tatmini üzerinde olumsuz etkisi olduğu belirtilmektedir (Wright, 2005; Yılmaz ve Aslan, 2013, Yılmaz ve Altınok, 2009). Yilmaz ve Aslan (2013) öğretmenler üzerinde yaptıkları araştırmada yaşam tatmini düzeyleri ile iş yaşamı yalnızlığının duygusal yoksunluk ve sosyal arkadaşlık boyutları arasında olumsuz bir 
ilişki olduğu ifade edilmiştir. Yalnızlık kavramı hem iş yaşamı hem de özel yaşamı kapsayan bir bütün olarak bireyin hayatı etkileyen bir kavramdır. Bu nedenle bireyin iş dışındaki hayatında hissettikleri iş yerindeki ilişkilerinde de etkili olmakta ve kendini yalnız, amaçsız ve işe yaramaz hisseden bireyin bu durumu daha kötü olumsuz durumlar yaşamasına neden olabilir. Yalnızlık hissine kapılan bireyin yaşama ilişkin beklentileri ve algıları zarar görmekte, yaşamaktan mutsuz bir insan olmasına neden olacaktır. İş yaşamı, sosyal yaşam ve özel yaşam ilişkileri bir bütün olarak bireyin ruhsal mutluluğunu oluşturduğu düşünüldüğünde, çalışanların iş yaşamlarındaki rekabetin ve çatışmaların bir sonucu olarak giderek artan iş yeri yalnızlığı hissi yaşamın diğer parçalarını da olumsuz olarak etkileyebilir. Yaşam tatmini, bireyin yaşamının her döneminde sahip olduğu sadece olumlu gelişim derecesi olduğu söylenebilir. Bu derece bireyin iş hayatını ve işine olan yaklaşımını etkileyecektir. Bu anlatılanlar sonucunda araştırmada öne sürülen ilk hipotez şu şekildedir;

Hipotez 1: İş yaşamında yalnızlık yaşam tatminini olumsuz yönde etkiler.

\section{İş Yaşamında Yalnızlık ile İş Tatmini İlişkisi}

İş tatmini kavramı ilk defa Hoppock (1935) tarafından, bir kimseyi "ben işimden genel anlamda memnunum" demeye sevk eden psikolojik, fizyolojik ve çevresel koşulların birleşimi olarak tanımlanmıştır. Daha sonra iş tatmini kavramı hakkında pek çok araştırma yapılmış ve farklı birçok tanım ortaya çıkmıştır. İş tatmininin iç ve dış faktörlerden kaynaklanan olmak üzere iki boyutu bulunmaktadır (Blenegen, 1993, s. 37). Birincisi, bireyin yapısı, duyguları, düşünceleri, istekleri ile içinde bulunduğu ihtiyaçlar ve bunların şiddet dereceleriyle ilgilidir. Bir başka deyişle, fiziksel, psikolojik ve güvenlik ihtiyaçlarıdır. İkincisi ise işe yönelik şartlardır. İşe yönelik fiziksel ve psikolojik koşullar ile bu koşulların bireyin beklentilerine cevap verebilme düzeyidir.

İş tatmininin kişinin işinin iş değerlerine ulaşması veya kolaylaştırması olarak değerlendirilmesinden kaynaklanan zevk aldığı duygusal durum olduğu ifade edilmiştir (Locke, 1969, s. 317). Çalışanların iş arkadaşlarıyla ilişki ve etkileşimlerinin önemli olması, iş yaşamında yalnızlık hissine sahip olan çalışanın iş tatmininin düşmesi beklenir. Literatürde iş yaşamı yalnızlığı ile iş tatmini arasındaki ilişkiyi inceleyen çok sayıda çalışma mevcuttur. Şişman ve Turan'ın (2004) yaptıkları araştırmaya göre, iş tatmini ile sosyal yalnızlık ve duygusal yalnızlık arasında bir ilişki yoktur. Wright'a (2005) göre iş yaşamı yalnızlığ 1 ile iş tatmini arasında olumsuz yönde ilişki vardır. Cindiloğlu ve arkadaşları (2017) yapmış oldukları araştırmada çalışanların iş yerindeki ilişkilerin önemli olması iş yaşamında yalnız kalan çalışanın iş tatmininin azalmasıyla doğrudan ilişkili olduğunu göstermektedir. Bu anlatılanlar sonucunda turizm sektöründe çalışanların iş yaşamında yalnızlık hisleri iş tatminlerini olumsuz şekilde etkileyeceği beklenmektedir. Bu nedenle araştırmada öne sürülen ikinci hipotez şu şekildedir;

Hipotez 2: İş yaşamında yalnızlık iş tatminini olumsuz yönde etkiler.

\section{İş Yaşamında Yalnızlık ile Çalışmaya Tutkunluk İlişkisi}

Örgütsel Davranış yazınında İngilizce karşılığı 'work engagement' olan kavram Türkçe'de 'çalışmaya tutkunluk' olarak isimlendirilmiştir (Turgut, 2010). Çalışmaya tutkunluk yönetimdeki en güncel konulardan biridir. Kahn (1990) bu kavramı ilk ortaya koyduğundan beri psikoloji, yönetim ve diğer alanlarda çok fazla ilgi görmüştür (Kahn, 1990). İşe katılım, çalışanların iş performansını etkili bir şekilde tahmin edebilir (Kahn, 1990). Çalışmaya 
tutkunluk olumlu, tatmin edici, işle ilgili bir zihin durumudur (Schaufeli vd., 2002, s. 74). Katılımı, nispeten kalıcı olan ancak zamanla dalgalanabilen bir zihin durumu olarak kavramsallaşmıştır (Schaufeli vd., 2002). Başka bir tanımda çalışmaya tutkunluk, pozitif, tatmin edici, çalışmayla ilgili bir ruhsal bir durum olarak tanımlanmıştır (Schaufeli vd., 2002, s. 74). Bu ruhsal durum dinçlik, adanmışlık ve yoğunlaşma olmak üzere üç boyut altında sınıflanmıştır. Dinçlik boyutu çalışırken yüksek enerji düzeyi, zihinsel dayanıklılık, çaba sarf etme isteği ve kolayca yorulmama yeteneğini içerir. Çalışırken muazzam bir dinçlik hisseden birey yaptığ devam eder. Adanmışlık çalışmaya yönelik güçlü bir bağlılığı temsil eder ve önemlilik hissi, şevk, ilham, övünç ve mücadele olgularını kapsar. Çalışmaya adanmış olan bireyler işlerinin ilgi çekici olduğunu, mücadele gerektirdiğini, bir amaca hizmet ettiğini ve anlamlı olduğunu düşünürler; yaptıkları iş onlara ilham verir, dolayısıyla işlerini hevesle yaparlar ve işleriyle gurur duyarlar. Yoğunlaşma bireyin yaptığı işe tamamen odaklanması ve mutlu bir şekilde çalışmaya odaklanmasıdır. Birey çalışırken yaptığı işe kendisini kaptırır, zamanın nasıl geçtiğini anlamaz ve çalışmaya ara vermekte zorlanır (Turgut, 2011'den akt. Şanlı, Tan ve Bozanoğlu, 2018, s. 74). Çalışanlar için zararlı sonuçları olan iş yaşamında yalnızlığının çalışmaya tutkunluk üzerinde etkisi olduğu söylenebilir. İşyerindeki diğer bireylerle yakınlık kurma kapasitesi veya istekliliği az olan bireylerin çalışmaya tutkun davranışlar sergileme olasılığı artmaktadır. Literatür incelendiğinde işyeri yalnızlığı ile çalışmaya tutkunluk arasındaki ilişkiyi inceleyen çok az sayıda araştırma olduğu görülmüştür. Bu anlatılanlar sonucunda araştırmada öne sürülen üçüncü hipotezi şu şekildedir;

Hipotez 3: İş yaşamında yalnızlık çalışmaya tutkunluğu olumsuz yönde etkiler.

\section{İş Yaşamında Yalnızlık ile Aracı Değişken İlişkileri}

Literatür iş tatmininin çalışmaya tutkunluk ile olumlu yönde ilişkili olduğunu göstermektedir (Garg vd., 2018). Bazı yazarlar çalışmaya tutkunluğun yeni bir yaklaşım olduğunu ve iş tatminine benzer olduğunu iddia etse de (Lavy ve Littman-Ovadia, 2017; Saks ve Gruman, 2018) birçok araştırmacı iş tatmini ve çalışmaya tutkunluğu birbirinden tamamen farklı olduğunu vurgulamıştır (Alarcon ve Lyons, 2011; Barnes ve Colliers, 2013). Tatmin çalışanlar işyerinde büyük olasılıkla zevkli bir duygusal durum yaşarlar (Biswas ve Bhatnagar, 2013), fakat iş tatmini üretkenlikle sonuçlanmayabilir (Abraham, 2012). Saks (2006). Çalışmaya tutkunluğun iş performansı ve çalışan refahının güvenilir bir yordayıcısı olması, bu farklılıkların, yapıların farklı doğalarının ürünleri olmasındandır. İş tatmini pasif ve duygusal bir durum iken, çalışmaya tutkunluk aktif bir memnuniyet halidir (van Wingerden vd., 2016). $\mathrm{Bu}$ nedenle araştırmalar, çalışma koşullarından, kuruluşun ödül sisteminden, iş ilişkilerinden ve terfi fırsatlarından memnun olan çalışanların muhtemelen işlerinde yer alacaklarını göstermektedir (Havens vd., 2018). İş tatmini, işin duygusal yönlerine, iş koşullarının veya özelliklerinin değerlendirici bir tanımına odaklanırken (Christian vd., 2011, s. 97), çalışmaya tutkunluk, katılımın fiziksel, duygusal ve bilişsel yönlerine bir bireyin işten kaynaklanan deneyimlerinin bir açıklaması olarak odaklanır (Christian vd., 2011, s.97).

Çalışmaya tutkunluk ile iş tatmini arasındaki benzerlik ve çalışmaya tutkunluğu yapısının benzersizliği (Newman ve Harrison, 2008) göz önüne alındığında, tatmin ve tutkunluğun aynı anda olası aracılık etkisinden söz edilebilir. Ertürk ve Erdirençelebi'ye (2018) göre çalışanların iş yaşamında yalnızlığı iş tatmini üzerinden işten ayrılma niyetini olumlu yönde 
etkilemektedir. Çalışanların iş tatmini (Saks, 2006), sağlık, örgütsel bağlılık (Saks, 2006; Simpson, 2009) ile pozitif ilişkili olduğu için çalışanlar ve kuruluşlar üzerinde olumlu bir etkiye sahiptir. Çalışmaya tutkunluk birçok çalışmada aracı değişken olarak modellenmiştir (Karatepe ve Talebzadeh, 2016; Karatepe ve Eslamlou, 2017; Chen ve Chen, 2012; Chen ve Kao, 2012).

Bireysel boyutlar çalışanların memnuniyetinin bu boyutların sonucu olduğu iş bağlılığına gömülüdür. Bu bulgu, enerji ve özveri ile güçlü ve pozitif iş bağlllığ1 olan çalışanın genellikle işinden memnun kaldığını gösteren başka bir çalışmayı doğrulamaktadır (Karanika-Murray vd., 2015). Diğer bir araştırma da çalışmaya tutkunlar ile işlerinden duydukları tatminleri arasında negatif bir ilişki olduğu ortaya çıkmıştır (Burke ve MacDermid, 1999). Bu arada Rayton ve Yalabık'ın (2014) çalışmasından bir sonuç, çalışanın işverenlerinin tüm yükümlülüklerini yerine getirdiğini hissettiğinde işiyle meşgul olduğunu ve bunun da iş memnuniyetini sağladığını göstermektedir. Bu bulgu, çalışmaya tutkunluk ve iş tatmini arasında pozitif bir ilişki olduğunu doğrulayan Yeh'in (2013) çalışmasıyla uyumludur. Yeh'den (2013) elde edilen bu bulgu, özel sektör bankasında çalışan yöneticilerin iş tatmini ile çalışmaya tutkunlukları arasındaki ilişkiyi araştıran ve sonuçların olumlu bir ilişki olduğunu gösteren yakın tarihli bir çalışmada doğrulanmıştır (Garg vd., 2018).

İş yerinde kendisini yalnız hisseden birey iş ortamındaki arkadaşlarıyla iletişim ve ilişkilerini zamanla azaltmakta ve olumsuz bir duygu hali içerisine girecektir. Bundan dolayı birey psikolojik, fiziksel ve sosyal açıdan kendisini her şeyden çekmeye yatkın bir duruma düşecektir. İş yerinde tüm yaşanılan olumsuzluklarla beraber sosyal ilişkilerinde de yetersizlik yaşayan ve tüm her şeyden memnun olamayan birey çalışmaktan bezecek ve işten kaytarma, işe geç gitme ya da işten ayrılma gibi eylemlerle sonuçlanacak bir duruma gelecektir. Bu anlatılanlar sonucunda araştırmada öne sürülen diğer hipotezler şu şekildedir;

Hipotez 4: İş tatmininin iş yaşamında yalnızlık ile yaşam tatmini arasında aracılık rolü vardır.

Hipotez 5: Çalışmaya tutkunluğun iş yaşamında yalnızlık ile yaşam tatmini arasında aracılık rolü vardir.

Hipotez 6: Çalışmaya tutkunluğun iş yaşamında yalnızlık ile iş tatmini arasında aracılık rolü vardir.

\section{Araştırmanın Yöntemi}

\section{Örneklem}

Araştırmada basit rastgele örnekleme yöntemi kullanılmış olup, örneklem Antalya' da turizm sektöründe görev yapan çoğunluğunun yöneticilerin oluşturduğu 338 çalışandan oluşmaktadır. Araştırma verileri 20 Mayıs 2019 - 20 Haziran 2019 zaman aralığında elde edilmiştir. Katılımcıların \%39,3'ü (133 kişi) kadın, \%60,7'si (205 kişi) ise erkektir. Çalışanların önemli bir kesimi (\%77,2'sine karşılık gelen 261 kişi) 18-35 yaş aralığındadır. Katılımcıların büyük çoğunluğu (\%82,5'ine karş1lık gelen 279 kişi) lise ve üniversite mezunlarından oluşmaktadır. Katılımcıların \%5'i medeni durumunu belirtmemiş, \%34,1'i (115 kişi) evli, \%60,9’u (206 kişi) ise bekâr olduğunu ifade etmişlerdir. Katılımcıların \%68,3'üne karşılık gelen 231 kişi yiyecek içecek departmanında çalıştığını belirtmiştir. Katılımcıların \%79,3’ü (268 kişi) yönetici pozisyonunda bulunmayan çalışanlardan oluşurken, geri kalanı şefler, departman müdür yardımcıları ve departman müdürlerinden oluşmaktadır. Çalışanlardan \%74,6'sı hali 
hazırda çalışmakta olduğu işletmedeki çalışma geçmişinin 5 yıla kadar olduğunu belirtmişlerdir. Çalışanların \%46,7'si sektördeki çalışma sürelerinin 5 yılı geçmediğini, \%24,9'u ise bu sürenin 10 yılı geçmediğini ifade etmiştir.

\section{Veri Toplama Araçları}

Araştırma verilerinin toplanmasında anket tekniğinden yararlanılmış olup anketler elden toplanmıştır. Ölçekler 5'li Likert şeklinde $(1=$ kesinlikle katılmıyorum, $5=$ kesinlikle katılıyorum ya da 1-hiç memnun değilim, 5-çok memnunum) tasarlanmıştır. Ölçeklerle birlikte, anket formunda birtakım demografik ifadelere de yer verilmiştir.

İş yaşamında yalnızlığı ölçmek için Wright vd.'nin (2006) geliştirdiği ve Doğan vd. (2009) tarafından Türkçe'ye uyarlanmış olan İş Yaşamında Yalnızlık Ölçeği (Loneliness at Work Scale-LAWS) kullanılmıştır. Toplam 16 ifadeden oluşan ölçek duygusal yoksunluk ve sosyal arkadaşlık olmak üzere iki alt boyuttan meydana gelmektedir. Duygusal yoksunluk boyutundaki ifadelere "Kendimi iş arkadaşlarımdan duygusal olarak uzak hissediyorum" ifadesi örnek verilebilirken; sosyal arkadaşlık boyutundaki ifadelere ise, "İş yerinde istediğimde kişisel düşüncelerimi paylaşabileceğim kimse yoktur" ifadesi örnek olarak verilebilir. Doğan vd.'nin (2009) çalışmasında ölçeğin genel Cronbach Alfa iç tutarlılık katsayısı 0,91; duygusal yoksunluk boyutunun 0,87; sosyal arkadaşlık boyutunun 0,83 olarak tespit edilmiştir.

Katılımcıların çalışmaya tutkunluklarının ölçülmesinde Schaufeli vd.'nin (2002) geliştirdiği ve Turgut (2011) tarafından Türkçe'ye uyarlanan Utrecht Çalışmaya Tutkunluk Ölçeği (Utrecht Work Engagement Scale-UWES) ölçeği kullanılmıştır. 17 ifadeden oluşan ölçek dinçlik, yoğunlaşma ve adanmışlık olmak üzere üç alt boyuttan oluşmaktadır. Dinçlik boyutunda "İşimde zihnimi çabuk ve güçlü şekilde toparlarım.", yoğunlaşma boyutunda "Çalışırken zamanın nasıl geçtiğini anlamam." ve adanmışlık boyutunda "Yaptığım işin anlamlı olduğunu ve bir amaca hizmet ettiğini düşünüyorum." ifadeleri örnek verilebilir. Turgut (2011) çalışmasında ölçeğin genel Cronbach Alfa iç tutarlılık katsayısını 0,89; dinçlik boyutunun 0,81 ; yoğunlaşma boyutunun 0,86 ve adanmışlık boyutunun 0,87 olarak tespit etmiştir.

Yaşam tatmininin ölçülmesinde Diener vd. (1985) tarafından geliştirilen ve Dağlı ve Baysal (2016) tarafından Türkçe'ye uyarlanan Yaşam Tatmini Ölçeği'nden yararlanılmıştır. 5 ifadeden oluşan ölçek tek boyutludur. Ölçekte geçen ifadelere, "İdeallerime yakın bir yaşantım vardır." ve "Şimdiye kadar yaşamdan istediğim önemli şeylere sahip oldum." örnek verilebilir. Dağlı ve Baysal'ın (2016) çalışmasında, ölçeğin Cronbach Alfa iç tutarlılık katsayısı 0,88 olarak tespit edilmiştir.

Katılımcıların iş tatminin ölçülmesinde 20 ifadeden oluşan Weiss vd. (1967) tarafından geliştirilen Minnesota İş Tatmini Ölçeği'nden yararlanılmıştır. Ölçek içsel iş tatmini ve dışsal iş tatmini olmak üzere iki boyuttan meydana gelmektedir. "Kendi yeteneklerimle bir şeyler yapabilme şansı vermesi yönünden" ifadesi içsel iş tatmini boyutundaki ifadelere örnek oluştururken, "yaptığım iş karşısında takdir edilmem yönünden" ifadesi ise dışsal iş tatmini boyutundaki ifadelere örnek oluşturmaktadır. Boz'un (2016) çalışmasında iş tatmini ölçeğinin genel Cronbach Alfa iç tutarlılık katsayısı 0,93; içsel tatmin boyutunun 0,89 ve dışsal tatmin boyutunun 0,90 olarak tespit edilmiştir. 


\section{İstatistiki İslemler}

Araştırmanın veri analizleri IBM SPSS 23 ve IBM SPSS AMOS 24 paket programları yardımıyla gerçekleştirilmiştir. IBM SPSS 23 yardımıyla, ölçeklerin güvenilirlik analizleri ve ana değişkenlerin korelasyon analizleri yapılmıştır. Araştırmada hipotezlerin testi yapısal eşitlik modellemesinden (YEM) yararlanılarak gerçekleştirilmiştir. YEM, IBM SPSS AMOS 24 paket programı ile yapılmıştır. Araştırmada aracılık etkisinin anlamlılı̆̆ı, Sobel Testi ile incelenmiştir.

\section{Bulgular}

Araştırmada yararlanılan ölçeklerin geçerliliğini test etmek için IBM SPSS AMOS 24 paket programından yararlanılarak doğrulayıc faktör analizi (DFA) gerçekleştirilmiştir. Çalışmada iyi uyum istatistikleri olarak Uyum İyiliği İndeksi (Goodness of Fit Index-GFI), Düzeltilmiş Uyum İyiliği İndeksi (Adjusted Goodness of Fit Index-AGFI), Ki-Kare İstatistiği (Chi-Square$\chi^{2}$ ) ve Yaklaşık Hataların Ortalama Karekökü (Root Mean Square Error of ApproximationRMSEA) değerleri kullanılmıştır. Meydan ve Şeşen'e (2011) göre, kabul edilebilir uyum için bahsi geçen istatistiklere dair $\chi^{2} / \mathrm{sd} \leq 5$; GFI $\geq 0,85$; AGFI $\geq 0,85$; RMSEA $\leq 0,08$ koşullarının karşılanması yeterli görülebilmektedir. Buna karşın, Bone vd. (1989) bazı durumlarda GFI ve AGFI'nın örneklem büyüklüğünden ya da modelin karmaşıklığından ötürü kritik değerin çok az altında gerçekleşebileceğini, bu haliyle de modelin kabul görebileceğini vurgulamaktadır. Hair vd. (1998) ise, RMSEA değerinin 0,08 ile 0,10 arasında gerçekleşmesi durumunda da, elde edilen değerin kabul edilebilir uyuma işaret edebileceğini savunmaktadır.

İki boyutlu İş Yaşamında Yalnızlık Ölçeği'nin birtakım modifikasyonlara gidilerek gerçekleştirilen DFA sonuçlarına bakıldığında, uyum iyiliği değerlerinin referans değerleri karşıladığ ve kabul edilebilir düzeyde olduğu tespit edilmiştir $\left[\chi^{2}(98, \mathrm{~N}=338)=416,89 ; \chi^{2} / \mathrm{sd}\right.$ $=4,25 ;$ GFI =0,87; AGFI =0,83; RMSEA =0,098]. Benzer şekilde, üç boyutlu Çalışmaya Tutkunluk Ölçeği'nin modifikasyonlu DFA sonuçları incelendiğinde, kabul edilebilir uyum değerlerinin karşılandığ görülmektedir $\left[\chi^{2}(114, \mathrm{~N}=338)=419,80 ; \chi^{2} / \mathrm{sd}=3,68 ; \mathrm{GFI}=0,87\right.$; AGFI = 0,82; RMSEA = 0,089]. İki boyutlu İş Tatmini Ölçeği'nin modifikasyonlu DFA sonuçları $\mathrm{da}$, ölçeğin mevcut haliyle kabul edilebilir uyum istatistiklerine sahip olduğunu göstermiştir $\left[\chi^{2}(166, \mathrm{~N}=338)=533,16 ; \chi^{2} / \mathrm{sd}=3,21 ; \mathrm{GFI}=0,86 ; \mathrm{AGFI}=0,82 ; \mathrm{RMSEA}=0,081\right]$. Diğer yandan, tek boyuttan oluştuğu için Yaşam Tatmini Ölçeği için DFA gerçekleştirilmemiştir.

Tablo 1'de araştırmanın ana değişkenlerinin ortalama değerleri, standart sapma değerleri, Pearson korelasyon katsayıları ve Cronbach Alfa güvenilirlik katsayılarına yer verilmiştir. Korelasyon analizi sonuçları değişkenler arasında farklı düzeylerde de olsa ilişkiler olduğunu ortaya koymuştur. Tablo incelendiğinde çalışanların iş yaşamında yalnızlığ (İYY) ile yaşam tatmini (YT) arasında olumsuz yönde zayıf ilişki $(\mathrm{r}=-0,21 ; \mathrm{p}<0,01)$; IYY ile iş tatmini (İT) arasında olumsuz yönde zayıf ilişki $(\mathrm{r}=-0,33$; $\mathrm{p}<0,01)$; IYY ile çalışmaya tutkunluk (ÇT) arasında olumsuz yönde zayıf ilişki $(r=-0,21 ; p<0,01)$ tespit edilmiştir. Ayrıca, YT ile İT arasında olumlu yönde orta düzey ilişki $(r=0,53 ; p<0,01)$; YT ile ÇT arasında olumlu yönde orta düzey ilişki $(r=0,43 ; \mathrm{p}<0,01)$ ve İT ile ÇT arasında olumlu yönde orta düzey ilişki $(\mathrm{r}=$ $0,53 ; \mathrm{p}<0,01)$ saptanmıştır.

Tablo 1. Değişkenlerin Ortalama, Standart Sapma, Güvenilirlik Katsayısı ve Korelasyon Değerleri 
İş Yaşamında Yalnızlık, Çalışmaya Tutkunluk, Yaşam Tatmini ve İş Tatmini Arasındaki İlişkilerin İncelenmesi: Turizm Sektörü İncelemesi

\begin{tabular}{lccccccc} 
Değişkenler & Ort. & S. S. & $\begin{array}{c}\text { Cronbach } \\
\text { Alfa }\end{array}$ & $\mathbf{1}$ & $\mathbf{2}$ & $\mathbf{3}$ & $\mathbf{4}$ \\
\hline 1. İş Yaşamında Yalnızlık (İYY) & 2,35 & 0,68 & 0,84 & 1,00 & $-0,21^{* *}$ & $-0,33^{* *}$ & $-0,21^{* *}$ \\
2. Yaşam Tatmini (YT) & 3,16 & 1,08 & 0,83 & $-0,21^{* *}$ & 1,00 & $0,53^{* *}$ & $0,43^{* *}$ \\
3. Isş Tatmini $\quad$ (IT) & 3,41 & 0,74 & 0,92 & $-0,33^{* *}$ & $0,53^{* *}$ & 1,00 & $0,53^{* *}$ \\
4. Çalışmaya Tutkunluk (ÇT) & 3,52 & 0,75 & 0,90 & $-0,21^{* *}$ & $0,43^{* *}$ & $0,53^{* *}$ & 1,00
\end{tabular}

${ }^{*} \mathrm{p}<0,05$ düzeyinde anlamll; ${ }^{* *} \mathrm{p}<0,01$ düzeyinde anlamlı.

Araştırmada hipotezlerin testinde YEM'den yararlanılmıştır. Şekil 1'de yer verilen ilk modelde bağımsız değişken olarak ele alınan iş yaşamında yalnızlığın, bağımlı değişken olan yaşam tatminine etkisi incelenmiştir. Bu modele ait uyum istatistikleri kabul edilebilir uyuma işaret etmektedir $\left[\chi^{2}(169, \mathrm{~N}=338)=634,63 ; \chi^{2} / \mathrm{sd}=3,76\right.$; GFI $=0,86$; AGFI $=0,80$; RMSEA = $0,090]$. Şekil 1'den anlaşıldığ üzere, iş yaşamında yalnızlığın yaşam tatmini üzerindeki etkisi $-0,20(p<0,05)$ olarak tespit edilmiştir. Elde edilen bu sonuç "Hipotez 1: İş yaşamında yalnızlık, yaşam tatminini olumsuz yönde etkiler." hipotezinin desteklendiğini ortaya koymaktadır.

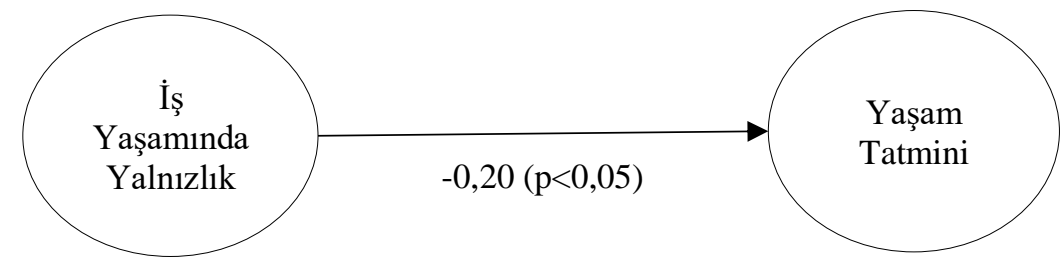

* $\mathrm{p}<0,05$ düzeyinde anlaml

Şekil 1. İş Yaşamında Yalnızlığın Yaşam Tatminine Doğrudan Etkisini Gösteren Model

Şekil 2'de yer verilen ikinci modelde, bağımsız değişken olarak ele alınan iş yaşamında yalnızlığın, bağımlı değişken olan iş tatminine etkisi araştırılmıştır. İyi uyum istatistiklerine ilişkin değerlendirmeler 1şığında bakıldığında, bu modelin değerlerinin kabul edilebilir uyuma işaret ettiği söylenebilmektedir $\left[\chi^{2}(573, \mathrm{~N}=338)=1476,96 ; \chi^{2} / \mathrm{sd}=2,58 ; \mathrm{GFI}=0,81\right.$; AGFI $=0,78$; RMSEA = 0,068]. Şekil 2'den anlaşıldığı üzere, iş yaşamında yalnızlığın iş tatmini üzerindeki etkisi -0,39 ( $p<0,05)$ olarak bulunmuştur. Bu bulgu “Hipotez 2: İ̧̧ yaşamında yalnızlık, iş tatminini olumsuz yönde etkiler." hipotezinin desteklendiğini göstermektedir.

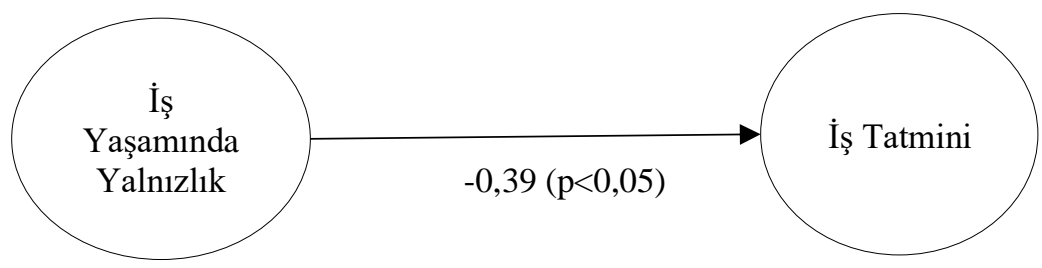

$\mathrm{p}<0,05$ düzeyinde anlaml

Şekil 2. İş Yaşamında Yalnızlığın İş Tatminine Doğrudan Etkisini Gösteren Model

Şekil 3'de yer verilen modelde, bağımsız değişken olarak ele alınan iş yaşamında yalnızlığın, bağımlı değişken olan çalışmaya tutkunluğa etkisi araştırılmıştır. Bu modelin de iyi uyum istatistiklerinin kabul edilebilir uyuma işaret ettiği söylenebilmektedir $\left[\chi^{2}(135, N=471)=\right.$ 
1458,55; $\chi^{2} / \mathrm{sd}=3,10 ; \mathrm{GFI}=0,79 ;$ AGFI = 0,75; RMSEA = 0,079]. Şekil 3'den anlaşıldığ 1 üzere, iş yaşamında yalnızlığın çalışmaya tutkunluk üzerindeki etkisi $-0,22 \quad(p<0,05)$ olarak bulunmuştur. Bu bulgu "Hipotez 3: İş yaşamında yalnızlık, çalışmaya tutkunluğu olumsuz yönde etkiler." hipotezinin desteklendiğine işaret etmektedir.

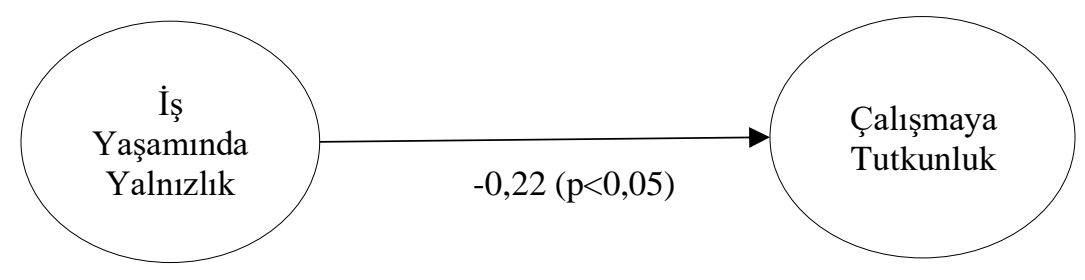

${ }^{*} \mathrm{p}<0,05$ düzeyinde anlamlı

Şekil 3. İş Yaşamında Yalnızlığın Çalışmaya Tutkunluğa Doğrudan Etkisini Gösteren Model

Hipotez 4, Hipotez 5 ve Hipotez 6'nın test edilmesinde aracı etkiye işaret eden modellerden yararlanılmıştır. Baron ve Kenny'e (1986) göre, bir değişkenin aracılık etkisinden bahsedilebilmesinde dört koşulun sağlanması gerekli görülmektedir. İlk koşul, bağımsız değişkenin bağımlı değişken üzerinde anlamlı etkiye sahip olmasıdır. İkinci koşul olarak ise, aracı değişkenin bağımlı değişken üzerinde anlamlı etkiye sahip olması şeklindedir. Aracı etkinin değerlendirilmesinde üçüncü koşul, bağımsız değişkenin aracı değişkeni anlamlı şekilde etkilemesi gerekliliğidir. Son koşul olarak, bağımsız değişkenin bağımlı değişken üzerindeki etkisinin aracı değişkenin modele dâhil edilmesiyle birlikte azalması ya da anlamsızlaşması gerekmektedir. Şayet aracı değişkenin devreye girmesiyle birlikte, sözü edilen etki tamamen anlamsızlaşıyorsa, aracı değişkenin tam aracılık etkisinin olduğundan; etkinin düzeyi düşüyor ise, aracı değişkenin kısmi aracılık etkisinin varlığından bahsedilebilmektedir.

Şekil 4'te iş yaşamında yalnızlı̆ı̆n yaşam tatminine etkisinde, iş tatmininin aracı rolünü gösteren hipotezi test etmek amaçlı geliştirilen modeli göstermektedir. Uyum istatistiklerine ilişkin değerlendirmeler göz önünde tutulduğunda, sözü edilen modele ilişkin uyum istatistiklerinin, kabul edilebilir uyuma işaret ettiği söylenebilmektedir $\left[\chi^{2}(748, N=338)=\right.$ 1694,$82 ; \chi^{2} / \mathrm{sd}=2,27 ; \mathrm{GFI}=0,81 ;$ AGFI = 0,78; RMSEA =0,061]. Şekil 1' de ele alınan ilk modelde bağımsız değişken iş yaşamında yalnızlı̆̆ın bağımlı değişken yaşam tatmini üzerindeki etkisi $-0,20(p<0,05)$ olarak tespit edilmiş olduğundan Baron ve Kenny'nin (1986) aracilık ile ilgili ilk koşulunun yerine getirildiği görülmektedir. Şekil 4'de yer alan ikinci modelde ise, iş tatmininin aracı etkisini gösteren diğer koşulların sağlandığ 1 görülmektedir. Şekil 4'de, aracı değişken olan iş tatmininin bağımlı değişken olan yaşam tatmini üzerindeki etkisi 0,54 $(p<0,05)$ olarak tespit edilmiş, bağımsız değişken olan iş yaşamında yalnızlığın aracı değişken olan iş tatmini üzerindeki etkisi de $-0,39(p<0,05)$ düzeyinde saptanmıştır. Şekil 4 ' de yer alan modelde, iş tatmininin aracı değişken olarak modele katılmasının sonucu olarak, iş yaşamında yalnızlığın yaşam tatmini üzerindeki etkisinin tamamen anlamsızlaştığı görülmüştür $(0,00$; p>0,05). Baron ve Kenny'e (1986) göre bu durum iş tatmininin, iş yaşamında yalnızlığın yaşam tatminine etkisinde tam aracılık rolü üstlendiğini ortaya koymaktadır. Bunun yanında, aracı etkinin anlamlılığını sorgulayan Sobel Testi'ne (Sobel, 1982) göre, iş tatmininin iş yaşamında yalnızlık ile yaşam tatmini arasında aracılık rolü üstlendiği teyit edilmiştir $(Z=-4,78 ; p<0,05)$. 
$\mathrm{Bu}$ bulgular çerçevesinde, "Hipotez 4: İş tatmininin, iş yaşamında yalnızlık ile yaşam tatmini arasında aracılık rolü vardır." hipotezi desteklenmektedir.

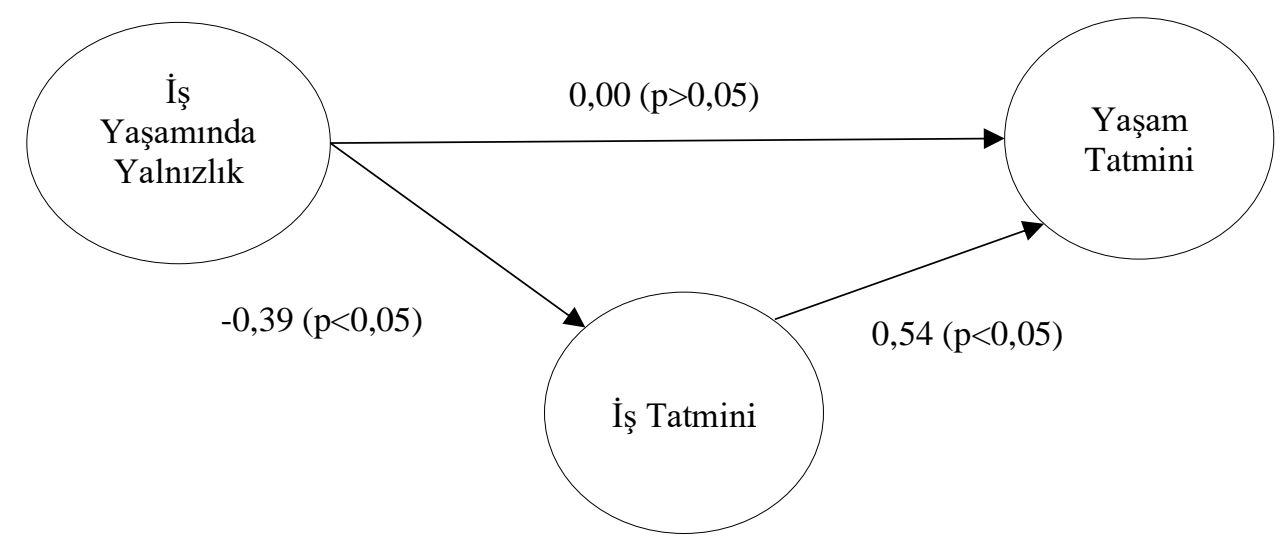

${ }^{*} \mathrm{p}<0,05$ düzeyinde anlamlı

Şekil 4. İş Yaşamında Yalnızlığın Yaşam Tatminine Etkisinde İş Tatmininin Aracı Rolünü

\section{Gösteren Model}

Şekil 5 iş yaşamında yalnızlığın yaşam tatminine etkisinde, çalışmaya tutkunluğun aracı rolünü gösteren hipotezi test etmek amaçlı geliştirilen modeli göstermektedir. Uyum istatistiklerine ilişkin değerlendirmeler göz önünde tutulduğunda, sözü edilen modele ilişkin uyum istatistiklerinin, kabul edilebilir uyuma işaret ettiği söylenebilmektedir $\left[\chi^{2}(631, N=338)\right.$ $=1660,63 ; \chi^{2} / \mathrm{sd}=2,63 ; \mathrm{GFI}=0,80 ; \mathrm{AGFI}=0,76 ;$ RMSEA $\left.=0,070\right]$. Şekil 1'de ele alınan ilk modelde bağımsız değişken iş yaşamında yalnızlığın bağımlı değişken yaşam tatmini üzerindeki etkisi -0,20 ( $p<0,05)$ olarak tespit edilmiş olduğundan Baron ve Kenny'nin (1986) aracılık ile ilgili ilk koşulunun yerine getirildiği görülmektedir. Şekil 5'de yer alan modelde ise, çalışmaya tutkunluğun aracı etkisini gösteren diğer koşulların sağlandığı görülmektedir. Şekil 5'de, aracı değişken olan çalışmaya tutkunluğun bağımlı değişken olan yaşam tatmini üzerindeki etkisi $0,43(p<0,05)$ olarak tespit edilmiş, bağımsız değişken olan iş yaşamında yalnızlığın aracı değişken olan çalışmaya tutkunluk üzerindeki etkisi de $-0,23 \quad(p<0,05)$ düzeyinde saptanmıştır. Şekil 5 'de yer alan modelde çalışmaya tutkunluğun aracı değişken olarak modele katılmasının sonucu olarak, iş yaşamında yalnızlığın yaşam tatmini üzerindeki etkisinin anlamsızlaşmadığı, ancak etki düzeyinin azaldığı görülmüştür $(-0,11 ; p<0,05)$.

Baron ve Kenny'e (1986) göre bu durum çalışmaya tutkunluğun, iş yaşamında yalnızlığın yaşam tatminine etkisinde kısmi aracılık rolü üstlendiğini ortaya koymaktadır. Diğer yandan, gerçekleştirilen Sobel Testi'ne (Sobel, 1982) göre, çalışmaya tutkunluğun iş yaşamında yalnızlık ile yaşam tatmini arasında aracılık rolü üstlendiği teyit edilmiştir $(Z=-3,21 ; p<0,05)$. Bu bulgulara bakıldığında, "Hipotez 5: Çalışmaya tutkunluğun, iş yaşamında yalnızlık ile yaşam tatmini arasında aracılık rolü vardır." hipotezi desteklenmektedir. 


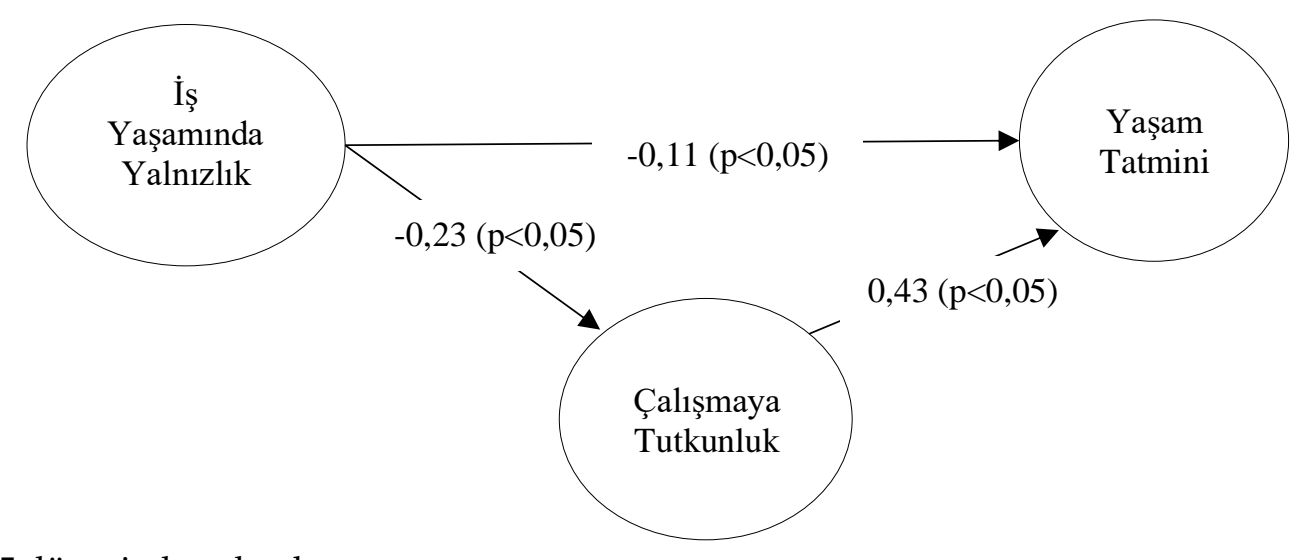

${ }^{*} \mathrm{p}<0,05$ düzeyinde anlamlı

Şekil 5. İş Yaşamında Yalnızlığın Yaşam Tatminine Etkisinde Çalışmaya Tutkunluğun Aracı Rolünü Gösteren Model

Şekil 6 iş yaşamında yalnızlığın iş tatminine etkisinde, çalışmaya tutkunluğun aracı rolünü gösteren hipotezi test etmek amaçlı geliştirilen modeli göstermektedir. Uyum istatistiklerine ilişkin değerlendirmeler göz önünde tutulduğunda, sözü edilen modele ilişkin uyum istatistiklerinin, kabul edilebilir uyuma işaret ettiği söylenebilmektedir [ $\chi^{2}(1287, \mathrm{~N}=338)=$ 3029,75; $\chi^{2} / \mathrm{sd}=2,35 ; \mathrm{GFI}=0,75 ; \mathrm{AGFI}=0,72 ; \mathrm{RMSEA}=0,063$ ]. Şekil 2' de ele alınan modelde bağımsız değişken iş yaşamında yalnızlığın bağımlı değişken iş tatmini üzerindeki etkisi -0,39 $(p<0,05)$ olarak tespit edilmiş olduğundan Baron ve Kenny'nin (1986) aracılık ile ilgili ilk koşulunun yerine getirildiği görülmektedir. Şekil 6'da yer alan modelde ise, çalışmaya tutkunluğun aracı etkisini gösteren diğer koşulların sağlandığ 1 görülmektedir. Şekil 6 ' da, aracı değişken olan çalışmaya tutkunluğun bağımlı değişken olan iş tatmini üzerindeki etkisi 0,56 $(p<0,05)$ olarak tespit edilmiş, bağımsız değişken olan iş yaşamında yalnızlı̆̆ın aracı değişken olan çalışmaya tutkunluk üzerindeki etkisi de $-0,24(p<0,05)$ düzeyinde saptanmıştır. Şekil 6 'da yer alan modelde çalışmaya tutkunluğun aracı değişken olarak modele katılmasının sonucu olarak, iş yaşamında yalnızlığın iş tatmini üzerindeki etkisinin anlamsızlaşmadığı, ancak etki düzeyinin azaldığı görülmüştür $(-0,25 ; \mathrm{p}<0,05)$. Baron ve Kenny'e (1986) göre bu durum iş yaşamında yalnızlığın iş tatminine etkisinde çalışmaya tutkunluğun kısmi aracılık rolü üstlendiğini ortaya koymaktadır. Ayrıca, gerçekleştirilen Sobel Testi'ne (Sobel, 1982) göre, çalışmaya tutkunluğun iş yaşamında yalnızlık ile iş tatmini arasında aracılık rolü üstlendiği teyit edilmiştir $(Z=-3,19 ; p<0,05)$. Bu bulgulara bakıldığında, "Çalışmaya tutkunluğun, iş yaşamında yalnızlık ile iş tatmini arasında aracılık rolü vardır." hipotezi desteklenmektedir.

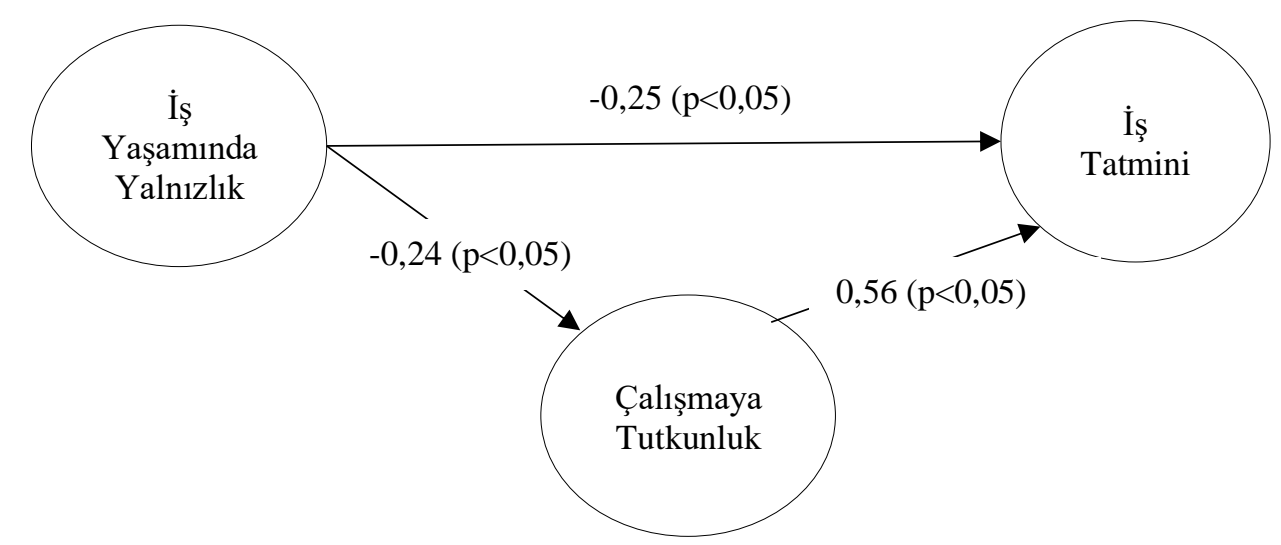

${ }^{*} \mathrm{p}<0,05$ düzeyinde anlamlı 
Şekil 6. İş Yaşamında Yalnızlığın İş Tatminine Etkisinde Çalışmaya Tutkunluğun Aracı Rolünü Gösteren Model

\section{Sonuç ve Tartışma}

Son yıllarda işletmelerin en önemli amaçlarının başında çalışanların yöneticileri ve çalışma arkadaşları ile sağlıklı iletişim kurmalarını sağlamaktır. Örgütlerin bu amaca önem vermelerinin nedeni ise çalışanların kendilerini sosyal çevreden kopuk ve duygusal olarak yalnız hissetmeleri olduğu söylenebilir. Sosyal bir çevreye sahip çalışanlara da nadiren rastlanılmakta ve gün geçtikçe bireyler çalışma şartları ve zorluklarının artmasıyla daha da yalnız hissetmeye ve yalnız kalmaya başladıkları söylenebilir.

$\mathrm{Bu}$ çalışmada da son zamanlarda ön planda olan ve birçok çalışanın maruz kaldı̆̆ 1 iş yaşamında yalnızlık kavramı ana değişken olarak incelenmiştir. İş yaşamındaki yalnızlığı, psikolojik sağlı̆̆ını ve iş performansını olumsuz yönde etkilediği düşünüldüğünde işyerinde yalnızlık, kişisel ve örgütsel hedefler arasındaki dengede bir bozukluğa neden olur, çalışanların iş tatmini ve üretkenliğini düşürür ve başarısızlık korkusunu, yetersizlik duygularını ve algılanan iş stresini teşvik eder. Bir işe yönelik bu tutumlar, çalışanların sağlığına (Faragher vd., 2005) ve genel yaşam memnuniyetlerine (Judge ve Watanabe, 1993) katkıda bulunur. Memnun çalışanlar meslektaşlarıyla daha iyi ilişkiler sürdürür (Swider vd., 2011), daha az işe gelmeme eğilimindedirler (Steel vd., 2002) ve daha az memnun olan meslektaşlarına göre işi bırakma olasılıkları daha düşüktür (Swider vd., 2011) ve örgütlerine daha fazla bağlılıkları vardır (Yoon ve Thye, 2002), ancak daha da önemlisi, iş tatmini yüksek yaşam tatmininin sürdürülmesine katkı sağlamaktadır.

Günümüzde örgütlerin rekabet üstünlüğü kazanmalarında en değerli kaynağın çalışanları olduğu değerlendirildiğinde, çalışanlarının verimliliği ve performansını etkileyecek her unsur için çalışanın kendisini mutlu hissetmesi, çalışma arkadaşları ve yöneticileriyle etkileşim içinde olması önem taşımaktadır. İş yerinde yalnızlık duygusu, fiziksel olarak birbirine yakın ya da uzak olmaktan kaynaklanan bir yalnızlık hissinden farklı olarak çalışanın kendisini sosyal etkileşimden izole hissettiği ve etrafında pek çok iş arkadaşı bulunurken kendisini duygusal olarak yalnız hissettiği durumdur. İş yerinde çalışanlar arasındaki etkileşim ve iletişim çoğunlukla fiziksel olarak birbirine yakın olmanın ötesine geçememektedir. İş yaşamında yalnızlık hisseden çalışan hem kendisini hem de içinde bulunduğu örgütü etkileyen sonuçların ortaya çıkmasına neden olmaktadır. İş yaşamında sağlıklı iletişim kuramayan ve yeteri kadar destek göremediğini düşündüğü için yalnızlık hissine kapılan bir çalışanın çalışmaya tutkunluk, yaşam ve iş tatmini düzeyleri olumsuz yönde etkilendiği söylenebilir.

Bu çalışmada turizm sektöründe çalışanların oluşturduğu örneklem üzerinde iş yaşamında yalnızlığın önce yaşam tatmini ile ilişkisi ve bu ilişkide iş tatmininin aracılık rolüne daha sonra ise iş yaşamında yalnızlığın yaşam tatmini ile ilişkisinde çalışmaya tutkunluğun aracılık rolüne odaklanılmıştır. Çalışanın iş yerinde ve özel hayatında olumsuzluklarla karşılaşmasına neden olan yalnızlık hissi iş tatmini ve çalışmaya tutkunluk ile daha iyi ve olumlu yönde etkilenmekte midir? araştırma sorusundan hareketle, işyeri yalnızlığının iş ve yaşam tatmini üzerindeki etkisinde iş tatmini ve çalışmaya tutkunluğun aracılık rolünün ne olacağına 
yönelik olarak bu araştırma tasarlanmıştır. Bu çalışma iki aşamalı araştırma tasarımı ile sınanan 6 hipoteze dayanmaktadır. Araştırmada iş yaşamı yalnızlı̆̆ı ile iş tatmini ve yaşam tatmini ilişkileri ilk bölüm de araştırılmıştır. Araştırmanın ikinci bölümünde ise iş tatmininin iş yaşamında yalnızlık ile yaşam tatmini arasında aracılık rolü üstlendiği; çalışmaya tutkunluğun iş yaşamında yalnızlık ile yaşam tatmini arasında aracılık rolü üstlendiği ve iş yaşamında yalnızlığın iş tatmini ilişkisinde çalışmaya tutkunluğun aracılık rolü üstlendiği teyit edilmiştir.

$\mathrm{Bu}$ çalışma iki nedenden dolayı işyeri yalnızlığına odaklanmaktadır. Öncelikle yalnızlık işyerinde yaygın bir sorundur. Bireysel düzeyde yalnızlık, strese, kötü sağlığa, depresyona, yaşam kalitesinin, iş tatminin ve çalışmaya tutkunluğun düşmesine yol açmaktadır. Becerilerini, enerjilerini ve ruh hallerini geliştiren çalışmaya tutkun çalışanlar, bu kaynakları kullanarak işyerinde daha iyi ilişkiler kurmakla birlikte, tutkunluk düzeylerini yükseltebilir ve bunu yaparken iş yaşamında yalnızlığı azaltabilir. Diğer neden ise iş yaşamında yalnızlık iş tatmini ve çalışmaya tutkunluğun aracılığıyla bireylerin hem yaşam tatminini hem de iş tatminini olumlu yönde etkilemektedir. Bu nedenlerden dolayı bu çalışmanın amacı iş yeri yalnızlığ 1 ile iş tatmini, yaşam tatmini ve çalışmaya tutkunluk kavramlarının alt boyutlarıyla birlikte aralarındaki ilişkileri kapsamlı ve detaylı olarak ortaya çıkarmak ve yazına katkı sağlamaktır. Böylelikle bu araştırmada çok değişkenli bir model kurgulanmış olup bağımsız değişken iş yaşamında yalnızlıktır. Diğer değişkenler ise; iş tatmini, kişinin işle bağlantılı kendi duyguları ve değerleri, ilerleme fırsatları ve işin özellikleriyle doğrudan ilişkili ve işe yönelik olumlu etkiler, yaşam tatmini bir kişinin yaşam kalitesinin seçtiği kriterlere göre genel bir değerlendirmesi ve çalışmaya tutkunluk ise kendini işe adama, işe anlam yükleme, işi özümseme, yüksek konsantrasyon ve işe dahil olmaya yönelik yüksek enerjiyi ifade etmektedir.

Sonuç olarak bu çalışmanın mevcut yazına birçok yönden katkı sağlamış olduğu ve yazındaki boşluğu doldurduğu değerlendirilmektedir. Bu çalışmanın sonuçlarına istinaden gelecekte yapılacak araştırmalar ve çalışmalar için bazı öneriler verilebilir. Öncelikle çalışma hayatı ve çalışma ilişkilerinin çalışanlar üzerindeki etkileri düşünüldüğünde iş yaşamında yalnızlığın bu çalışmada ele alınan yaşam ve iş tatmini ile çalışmaya tutkunluk dışındaki örgütsel davranış konu veya kavramlarıyla da ilişkilendirilerek araştırılması daha farklı boyutlar ve bakış açıları sunacaktır. Birçok değişkenin eş zamanlı olarak araştırma modeline katıldığı araştırma bulgularının etkilerin ve etkileşimlerin ortaya çıkma nedenleri ve sebep olunan sonuçların daha iyi anlaşılmasını sağlayacaktır.

\section{Kaynakça}

Abraham, S. (2012). Job satisfaction as an antecedent to employee engagement. SIES. Journal of Management, 8(2), 27-36.

Alarcon, G., ve Lyons, J. (2011). The relationship of engagement and job satisfaction in working samples. The Journal of Psychology, 145(5), 463-480.

Barnes, D. C. \& Collier, J. E. (2013). Investigating work engagement in the service environment. Journal of Services Marketing, 27(6), 485-499. 
Baron R. M., \& Kenny, D.A. (1986). The moderator-mediator variable distinction in social psychological research: Conceptual, strategic, and statistical considerations. Journal of Personality and Social Psychology, 51(6), 1173-1182.

Barron, C. R., Foxall, M. J., Dollen, K. V., Jones, P. A., \& Kelly, A. S. (1994). Marital status social support and loneliness in visually impaired elderly people. Journal of Advanced Nursing $19,272-280$.

Biswas, S., \& Bhatnagar, J. (2013). Mediator Analysis of Employee Engagement: Role of Perceived Organizational Support, P-O Fit, Organizational Commitment and Job satisfaction. The journal of Decision Makers, 38(1), 27-40.

Blenegen, M. A., (1993). Nurses' Job Satisfaction: A Meta-Analysis of Related Variables. Nursing Research, Jan-Feb, 42(1), 36-41

Bone, P. F., Sharma, S., \& Shimp, T.A. (1989). A Bootstrap Procedure for Evaluating Goodness-of-Fit Indices of Structural Equation and Confirmatory Factor Models. Journal of Marketing Research, 26(1), 105-111.

Boz, H. (2016). Yöneticilerin yetenek yönetimi yetkinliklerinin işten ayrulma niyeti ile ilişkisinde duygusal bağhllık, çalışmaya tutkunluk ve iş tatmininin aracılık etkisi: Bankacılık sektöründe bir araştırma, Yayımlanmamış Doktora Tezi, Akdeniz Üniversitesi Sosyal Bilimler Enstitüsü, Antalya.

Burke, R. J., \& MacDermid, G. (1999). Are workaholics job satisfied and successful in their careers? Career Development International, 4, 277-282.

Chan, S.H., \& Qiu, H. H. (2011). Loneliness, Job satisfaction, and organizational commitment of migrant workers: Empirical evidence from China. The International Journal of Human Resource Management, 22(5), 1109-1127.

Chen, C.-F., \& Chen, S.C. (2012). Burnout and work engagement among cabin crew: antecedents and consequences. Int. J. Aviat. Psychol. 22, 41-58.

Chen, C.F., \& Kao, Y.L. (2012). Moderating effects of work engagement and job tenure on burnout-performance among flight attendants. J. Air Transp. Manag. 25, 61-63.

Christian, M. S., Garza, A. S., \& Slaughter, J. E. (2011). Work engagement: A quantitative review and test of its relations with task and contextual performance. Personnel Psychology, 64, 89-136.

Christopher, J. C. (1999). Situating psychological well-being: exploring the cultural roots of its theory and research. Journal of Counseling ve Development, 77(2), 141-153.

Cindiloğlu, M, Polatcı, S, Özçalık, F. ve Gültekin Z. (2017). İşyeri Yalnızlığının İş ve Yaşam Tatminine Etkisi: Lider-Üye Etkileşiminin Aracılık Rolü. Ege Akademik Bakış Dergisi, 17(2), 191-200.

Çetin, A., \& Alacalar, A. (2016). İş yaşamında yalnızlığı yordamada kişilik özellikleri ile algılanan sosyal ve örgütsel desteğin rolü, Uluslararası Yönetim İktisat ve İşletme Dergisi, 12(27), 193-216. 
Dağlı, A., \& Baysal, N. (2016). Yaşam doyumu ölçeğinin Türkçe'ye uyarlanması: Geçerlik ve güvenirlik çalışması, Elektronik Sosyal Bilimler Dergisi, 15(59), 1250-1262.

Diener, E., Emmons, R. A., Larsen, R. J., \& Griffin, S. (1985). The satisfaction with life scale, Journal of Personality Assessment, 49 (1), 71-75.

Doğan, T., Çetin, B., \& Sungur, M. Z. (2009). İş Yaşamında Yalnızlık Ölçeği Türkçe formunun geçerlilik ve güvenilirlik çalışması, Anadolu Psikiyatri Dergisi, 10, 271-277.

Ertürk, E., \& Erdirençelebi, M., (2018). Çalışanların Örgütsel Yalnızlık Algısının İş Tatmini ve İşten Ayrılma Niyeti Üzerine Etkileri, Gaziantep University Journal of Social Sciences, 17(2), 603-618.

Faragher, E. B., Cass, M. \& Cooper, C. L. (2005). The relationship between job satisfaction and health: A meta-analysis. Occupational and Environmental Medicine, 62, 105-112.

Garg, K., Dar, A. F., \& Mishra, M. (2018). Job satisfaction and work engagement: A study using a private sector bank. Advances in Developing Human Resources, 20(10), 58-71.

Hair, J. F., Anderson, R. E., Tatham, R. L. ve Black, W. C. (1998). Multivariate Data Analysis, Pearson Education, New Jersey.

Havens, D. S., Gittell, J. H., \& Vasey, J. (2018). Impact of relational coordination on nurse job satisfaction, work engagement and burnout: Achieving the quadruple aim. The Journal of Nursing Administration, 48(3), 132-140.

Hawkley, L. C., \& Cacioppo, J. T. (2010). Loneliness matters: a theoretical and empirical review of consequences and mechanisms. Annals of Behavioral Medicine, 40(2), 218-227.

Hoppock, R. (1935). Job Satisfaction. Harper, Oxford.

Judge, T., \& Watanabe, S. (1993). Another Look at the Job Satisfaction-Life Satisfaction Relationship. Journal of Applied Psychology, 78, 939-948.

Kahn, A. W. (1990). Psychological Conditions of Personal Engagement and Disengagement At Work. Academy of Management Journal, 33(4), 692-724.

Karacaoğlu, K., \& Yumuk, Y. (2014). İşgören yalnızlı̆̆ııın bir öncülü olarak örgütsel dışlanma: beş yıldızlı otel işletmeleri çalışanları üzerine bir araştırma, 15.Ulusal Turizm Kongresi Bildiriler Kitabı, 13-16 Kasım 2014, Ankara: Nobel Yayın Dağıtım, 552-577.

Karanika-Murray, M., Duncan, N., Pontes, H.M., \& Griffiths, M.D. (2015). Organizational identifi cation, work engagement, and job satisfaction. Journal of Managerial Psychology, 30, 1019-1033.

Karatepe, O.M., \& Talebzadeh, N., (2016). An empirical investigation of psychological capital among flight attendants. J. Air Transp. Manag. 55, 193-202

Karatepe, O.M., \& Eslamlou, A., (2017). Outcomes of job crafting among flight attendants. J. Air Transp. Manag. 62, 34-43.

Kavanagh M.J., \& Halpern M. (1977). The Impact of Job Level and Sex Differences on the Relationship Between Life and Job Satisfaction. Academy of Management Journal, 20, 66-73 
Lam, L. W., \& Lau, D. C. (2012). Feeling lonely at work: Investigating the consequences of unsatisfactory workplace relationships. The International Journal of Human Resource Management, 23(20), 4265-4282.

Lavy, S., \& Littman-Ovadia, H. (2017). My better self: Using strengths at work and work productivity, organizational citizenship behavior, and satisfaction. Journal of Career Development, 44(2), 95-109.

Linn, L. S., Yager, J., \& Cope, D. (1985). Health status, job satisfaction, job stress and life satisfaction among academic andclinical faculty. JAMA, 254(19): 2775-2782.

Locke, E. A. (1969). What is job satisfaction? Organizational Behavior and Human Performance, 4, 309-336.

Lyubomirsky, S., King, L., \& Diener, E. (2005). The benefits of frequent positive affect: Does happiness lead to success? Psychological Bulletin, 131(6), 803-855.

Marangoni, C., \& Ickes, W. (1989). Loneliness: A theoretical review with implications for measurement. Journal of Social and Personal Relationships, 6(1), 93-128.

Mercan, N., Oyur, E., Alamur, B., Gul, S., \& Bengul S. (2012). İş yeri yalnızlığı ve sosyal fobi arasındaki ilişkiye yönelik bir araştırma, Organizasyon ve Yönetim Bilimleri Dergisi, 4(1), 213226.

Meydan, C. H., \& Şeşen, H. (2011). Yapısal Eşitlik Modellemesi AMOS Uygulamaları, Ankara, Detay Yayincilik.

Murthy, V. (2017). Work and the Loneliness Epidemic, Harward Busiess Rewiev, the Big Idea Series

Newman, D. A., \& Harrison D. A. (2008). Been there, bottled that: Are state and behavioral work engagement new and useful construct "wines"? Industrial and Organizational Psychology, 1, 31-35.

Öge, E., Çetin, M., \& Top, S. (2018). The effects of paternalistic leadership on workplace loneliness, work family conflict and work engagement among air traffic controllers in Turkey, Journal of Air Transport Management, 66, 25-35.

Özçelik, H., \& Barsade, S. G. (2018). No Employee an Island: Workplace Loneliness and Job Performance. Academy of Management Journal, 61 (6) amj.2015.1066.

Perlman, D., \& Peplau, L. A. (1982). Loneliness: A Sourcebook of Current Theory, Research and Therapy. New York: Wiley.

Rayton, B. A. \& Yalabik, Z.Y. (2014). Work engagement, psychological contract breach and job satisfaction. The International Journal of Human Resource Management, 25, 2382-2400.

Saks, A. M. (2006). Antecedents and consequences of employee engagement. Journal of Managerial Psychology, 21, 600-619.

Saks, A. M., \& Gruman, J. A. (2018). Socialization resources theory and newcomers' work engagement: A new pathway to newcomer socialization. Career Development International, 23(1), 12-32. 
Schueller, S. M., \& Seligman, M. E. P., (2008). Optimism and Pessimism, Risk Factors in Depression. 171-194.

Simpson, M. R. (2009). Engagement at work: A review of the literature. International Journal of Nursing Studies, 46, 1012-1024.

Shin, D., \& Johnson, D. (1978). Avowed happiness as an overall assessment of the quality of life. Social Indicators Research, 5(4), 475-492.

Schaufeli, W. B., Salanova, M., Gonzalez-Roma, V., \& Bakker, A. B. (2002). The measurement of engagement and burnout: A two sample confirmatory factor analytic approach, Journal of Happiness Studies, 3, 71-92.

Sekhon, S. K., \& Srivastava, M. (2019). Conquering workplace loneliness Individual or organization accountability. Human Resource Management International Digest. Emerald Insight (listed in ABDC journal category)

Sobel, M. E. (1982). Asymptotic confidence intervals for indirect effects in structural equation models, Sociological Methodology, 13, 290-312.

Steel, R. P., Rentsch, J. R., \& Hendrix, W. H. (2002). Cross-level replication and extension of Steel and Rentsch's (1995) longitudinal absence findings. Journal of Business \& Psychology, $16,447-456$.

Swider, B. W., Boswell, W. R., \& Zimmerman, R. D. (2011). Examining the job searchturnover relationship: The role of embeddedness, job satisfaction, and available alternatives. Journal of Applied Psychology, 96, 432-441.

Şanlı, Ö., Tan, Ç., \& Bozanoğlu, B. (2018). Öğretmenlerin okul yöneticilerinin iletişim becerilerine ilişkin görüşleri, Akademik Sosyal Araştırmalar Dergisi, 6(85),7-20.

Şişman, M., \& Turan, S. (2004). Bazı örgütsel değişkenler açısından çalışanların iş doyumu ve sosyal-duygusal yalnızlık düzeyleri (meb şube müdür adayları üzerinde bir araştırma), Osmangazi Üniversitesi Sosyal Bilimler Dergisi, 5(1), 117-128.

Theeke, L. A., Goins, R. T., Moore, J., \& Campbell, H. (2012). Loneliness, depression, social support, and quality of life in older chronically ill Appalachians. The Journal of Psychology, $146(1-2), 155-171$.

Turgut, T. (2010). Çalışmaya Tutkunluk, G. İslamoğlu (der.), Kurumlarda İyilik de Var. Nobel, Ankara, 57-89.

Turgut, T. (2011). Çalışmaya Tutkunluk: İş Yükü, Esnek Çalışma Saatleri, Yönetici Desteği ve İs-Aile Çatışması İle İlişkileri, Atatürk Üniversitesi İktisadi ve İdari Bilimler Dergisi, 25(3-4), 155-179.

Van Wingerden, J., Bakker, A. B., \& Derks, D. (2017). Fostering employee well-being via a job crafting intervention. Journal of Vocational Behavior, 100, 164-174.

Veenhoven, R. (1996). The study of life satisfaction. In: W. E. Saris, R. Veenhoven, A. C. Scherpenzeel, ve B. Bunting (Eds). A comparative study of satisfaction with life in Europe. 11-48. Eötvös University Press. 
Yeh, C. M. (2013). Tourism involvement, work engagement and job satisfaction among frontline hotel employees. Annals of Tourism Research, 42, 214-239.

Yılmaz, E., \& Altınok, V. (2009). Okul Yöneticilerinin yalnızlık ve yaşam doyum düzeylerinin incelenmesi kuram ve uygulamada eğitim yönetimi, Kuram ve Uygulamada Eğitim Yönetimi, 15(59), 451-469.

Yılmaz, E., \& Aslan, H. (2013). Öğretmenlerin İş Yerindeki Yalnizliklari ve Yaşam Doyumlari Arasindaki İlişkinin İncelenmesi, Pegem Journal of Education \& Instruction, 3(3), 59-69

Yoon, J., \& Thye, S. R. (2002). A dual process model of organizational commitment: Job satisfaction and organizational support. Work and Occupations, 29, 97-124.

Yurcu, G., \& Kocakula, Ö. (2015). Konaklama İşletmelerinde Çalışan Yalnızlığının Öznel İyi Oluş Üzerine Etkisi, Adnan Menderes Üniversitesi Sosyal Bilimler Enstitüsü Dergisi, 1, 30-41.

Weiss, D. J., Dawis, R. W., England, G. W., \& Lofquist, L. H. (1967). Manual for the Minnesota Satisfaction Questionnaire, Minnesota Studies in Vocational Rehabilitation.

Weiss, R. S. (1973). Loneliness: The experience of emotional and social isolation. Cambridge, MA: MIT Press.

West, D. A., Keliner, R., \& West, M. M. (1986). The Effects of loneliness: A review of the literature. Compr Psychiatry, 27(4), 351-363.

Wright, S. L. (2005). Loneliness in the workplace. Stat. Ber. http://dx.doi.org/10.1016/ S17469791(05)01106-5.

Wright, S. L., Burt, C. D. B., \& Strongman, K. T. (2006). Loneliness in the workplace: Construct definition and scale development, NZ J Psychol, 35, 59-68. 